\title{
Performance of brazilian state capitals as tourism destinations
}

\section{Desempenho das capitais brasileiras como destinos turísticos}

\section{Rendimiento de las capitales brasileñas como destinos turísticos}

\author{
Erick da Silva Santos ${ }^{1}$ \\ Mauri Fortes ${ }^{2}$
}

\begin{abstract}
This article introduces the application of Data Envelopment Analysis (DEA) associated with factor analysis to evaluate the relative efficiency of tourism demand of 18 Brazilian capital cities within a threeyear period. Such assessment includes data on factors that affect tourism demand as cities' budgets allocated on health, transportation, security, infrastructure, tourism as well as the result of this investment on number of tourist arrivals and creation of employments in each destination. The results show the capitals that reached $100 \%$ efficiency and also the only three capitals that touched the maximum efficiency over the three years. Findings also revealed that factor analysis associated with DEA offers a potential tool for managers to provide themselves with a set of practical indicators that better assist in decision-making regarding investment on sectors that positively interfere the demand in tourism locations.
\end{abstract}

Keywords: Efficiency. Data Envelopment Analysis (DEA). Factor Analysis. Tourism Demand. Brazilian Tourism Destinations.

Resumo: Este artigo apresenta a aplicação da Análise por Envoltória de Dados (DEA) associada à Análise Fatorial para avaliar a eficiência relativa da demanda turística de 18 capitais brasileiras por um período de três anos. Essa avaliação inclui dados sobre os fatores que influenciam na demanda do turismo tais como os investimentos das cidades alocados para a saúde, transporte, segurança, infraestrutura, turismo, bem como o efeito deste investimento no número de chegadas de turistas e criação de empregos em cada destino. Os resultados mostram as capitais que atingiram 100\% de eficiência e também as únicas três capitais que atingiram a máxima eficiência ao longo dos três anos. Os resultados também revelaram que a Análise Fatorial associado à DEA oferece uma ferramenta potencial para os gestores a fim de prover um conjunto de indicadores práticos que melhor auxiliam na tomada de decisões sobre investimentos em setores que interferem positivamente na demanda nos destinos turísticos.

1 UFT, Universidade Federal do Tocantins, Departamento de Turismo, Rua Paraguai S/N, Araguaína (TO). E-mail adress: erick.viagens@yahoo.com.br (E.S. Santos)

2 UNA, Centro Universitário, Departmento de Pós-graduação, Pesquisa e Extenção, Rua Guajajaras, 175, $5^{\circ}$ andar, 30180-100, Centro, Belo Horizonte (MG). E-mail adress: mauri.fortes@terra.com.br (M. Fortes)

This article is part of the paper completion at the Master Program in Tourism and Environment (UNA University). The Government of Tocantins (Brazil) has financially supported the corresponding author in taking such a program. The present address of corresponding author: 108 Norte, Alameda 14, n. 27, Palmas (TO) Brazil, 77006-116. 
Palavras-chave: Eficiência. Análise por Envoltória de Dados (DEA). Análise Fatorial. Demanda Turística. Destinos Turísticos Brasileiros.

Resumen: Este artículo presenta la aplicación del Análisis Envolvente de Datos (DEA) asociado con el análisis factorial para evaluar la eficiencia relativa de la demanda turística de 18 capitales brasileñas, en un plazo de tres años. Esta evaluación incluye datos sobre los factores que afectan la demanda turística ya que los presupuestos asignados ciudades en la salud, el transporte, la seguridad, la infraestructura, el turismo, así como el efecto de estas inversiones en el número de llegadas de turistas y la creación de empleos en cada destino. Los resultados muestran las capitales que alcanzaron una eficiencia del $100 \%$ y también los únicos tres capitales que tocaron la máxima eficiencia en los tres años. Los resultados también revelaron que el análisis de factores asociados con la DEA ofrece una herramienta potencial para los gerentes de dotarse de un conjunto de indicadores prácticos que ayudan a una mejor toma de decisiones respecto a la inversión en sectores que afectan positivamente la demanda en lugares turísticos.

Palabras clave: Eficiencia. Análisis Envolvente de Datos (DEA). Análisis Factorial. Demanda Turística. Destinos Turísticos Brasileños.

\section{INTRODUCTION}

Considered as complex networks that involve a large number of co-producing actors delivering a variety of products, and services (as transportation, accommodation, and food) tourism destinations has contributed for the economy of many countries (Gunn, 1994; UNWTO, 2010). Barros et al. (2011) define tourism destination as a geographical area where tourists enjoy and try various types of experience. Such areas can be a country, a city, a region or a specific local. For this paper we state as destination the Brazilian State capitals which is perceived by the research as a unit and its efficiency depends on how coordinated and integrated the tourism suppliers' products and services are to compete in a globalized and technological market (McGarvey \& Hannon, 2004).

A tourism city's competitiveness evaluation is important specially when destinations strive for bigger market shares. Tourism managers have to identify and explore competitive advantages and analyze the destination's rank. The degree to which a city can benefit from its tourism sector depends largely on this sector's competitive position and can be assessed in the national tourism scenario using statistical tools. For measuring the efficiency of any kind of unit (in this case a tourism destination) a range of techniques has approached for the evaluation of a production system. The efficiency of an organization (production unit) can be measured by the comparison of values in the production process that relates the maximum to be done with the same amount of a given supplier (Tupi \& Yamaguchi, 1998; Souza, 2008; Guimarães, 2009).

Regarding the efficiency on the tourism process Fuchs (2004) proposed that the development of products or services should address strategies that allow the investigation of the efficiency of tourism service production processes on the level of tourism destinations, therefore that is possible to benchmark the tourism destinations. 
Brazil has emerged the $21^{\text {st }}$ century as one of the outstanding countries in the economy, especially in the beginning of 2012 when it displaced United Kingdom from the $6^{\text {th }}$ position of the largest economy in the world. Such a growth is expected to capitalize on a buoyant domestic economy, plus the double public relations' coup of hosting the soccer World Cup in 2014 and Olympic Games in 2016. However, that comes up the importance of adopting strategic policies decisions for consolidating a sustainable growth, which implies evaluate the performance of tourism destinations, mainly because in the World Tourism Organization's perspectives the emerging destinations (Brazil, Russia, and China) will continue lead the growth in tourism (UNWTO, 2010).

For this paper is applied a very well-known statistical tool called DEA (Data Envelopment Analysis) for the evaluation of 18 State capitals in Brazil. The method, which according to the literature was used only in a few studies for benchmarking destinations in Brazil, is based on its level of inputs and outputs (Golany \& Roll, 1989).

The paper also aims to explain the sources of efficiency variations between the different destinations. For that purpose, a two-stage procedure is employed, where in the first stage the variables are separated into inputs and outputs for running factor analysis which reduces and group correlated variables. Then followed in the second stage by running DEA using the factors originated by Factor Analysis. The DEA results provide destination managers with information about the technical efficiency level of the destination, the variables that have contributed more, the inputs which should be improved and the efficient destinations which are benchmarks for the inefficient destinations.

\section{DATA ENVELOPMENT ANALYSIS AND FACTOR ANALYSIS: A THEORETICAL APPROACH}

By the combination of Farrel (1957) and Leibenstein (1966) ideas Charnes, Cooper, and Rhodes (1978) developed a technician to evaluate the efficiency of entrepreneurs' productivity of a same segment: the Data Envelopment Analysis (DEA). Basically it describes a mathematical programming approach for the construction of production frontiers and the measurement of efficiency in relation to the constructed frontiers.

In measuring the efficiency of each tourism destination, we used this well-known method in our tourism research. DEA, which is a nonparametric, multifactor analysis tool, considers multiple input variables and multiple output variables to evaluate relative efficiencies of organizations, institutions or destinations that are calculated by comparing the performance of each decision-making unit (DMU) against the best units (Barros, 2005; Shu, Zhong \& Zhang, 2011). The inputs and outputs of a given DMU are compared with the inputs and outputs of a convex combination of all DMUs of a similar activity. Then, one DMU is considered efficient if no other one is higher than it (Marinho, 1996). DEA highlights the best performing units and sets the stage for improving practices (Medina, Gomes \& Marrero, 2012). 
In this tourism research, due to many important variables available for running DEA, it was considered suitable use factor analysis technique which is used for data reduction by structuring many variables into a much smaller number of components or factors. Aranha \& Zambaldi (2008) affirm that factor analysis is a statistical method that examines a group of variables directly measured related to a small number of variables not directly measured. According to Johnson \& Wichern (1998) the main objective of factor analysis is describe the covariance relation between multiple variables based in a small group of non-observed variables which is called common factors (Green, 1976). The variables are grouped based on their correlation and that means that the number of factors will be much smaller than before. Each group of variables represents a factor which is responsible for correlations observed.

In the factor analysis model each variable is defined as a linear combination of common factors that will explain a portion of variance of each variable and that is known as communalities. For the portion which is not explained is called specificity (Hair Jr., J. F. Black, W. C. Babin, B. J. Anderson, R. E. \& Tathan, R. L., 1998). Although, for contemplating an acceptable factor analysis the literature suggests tests of sphericity and the KMO and Bartlett's tests of sphericity produces the Kaiser-Meyer-Olkin measure of sampling adequacy and Bartlett's test. Malhotra (2004) and Hair Jr. et al. (1998) consider that a KMO between 0.5 to 1.0 indicates as adequate for running factor analysis.

\section{TOURISM AS AN ECONOMIC ACTIVITY}

Tourism is characterized as a wealth generator, providing funds for the equilibrium of the commercial balance of countries. It is still valued by many authors as one of the world activities, along with the oil industry and its derivatives, weapons, motor vehicles, telecommunications equipment, textiles and other activities and services (Rabahy, 2003; Guimarães, 2009). Over the past three decades the tourism has achieved a significant economic performance for the Gross Domestic Product (GDP) of many countries, as an example Travel \& Tourism directly or indirectly support 76\% of all jobs in Aruba, 31\% in Belize and 27\% in Namibia (WTTC/OXFORD ECONOMICS, 2011). According to the World Tourism Barometer (UNWTO, 2012) the international tourist receipts surpass US\$ 1 trillion in 2011, hitting a new record and the tourist arrivals reached the mark of 982 million visitors. That means a growth of $3.8 \%$ in comparison to 2010 and the international arrivals grew $4.6 \%$ in the same period.

If comparing to the global GDP, in what tourism represents $9 \%$, the tourism in Brazil has a modest participation of only $3.4 \%$ in the national GDP (WTTC/OXFORD ECONOMICS, 2011). Nevertheless, it is facing a great opportunity to increase this minor rate for the next decade due to the hosting of soccer World Cup and the Olympic Games. In line with UNWTO publishing Tourism Towards 2030 - the forecast for the next ten years in Brazil is equivalent to a growth around $12 \%$ per annum, the fastest ratio in the world. That would raise the contribution for the 
national GDP at a range of $6 \%$. The actual 5.4 million international tourist arrivals are predicted to enhance to 10 million by 2020 (UNWTO, 2011). Comparing the first six months of 2010 with the same period in 2003, when Embratur (Brazilian Tourism Institute) started to take care exclusively of the tourist promotion of the country abroad, the flow exchange in Brazil grew by $164 \%$. The calculation of the Central Bank included official currency exchanges and expenses with international credit cards.

Despite all the positive predictions to Brazil the country has a lack of statistical studies, specifically those related to measurement of efficiency. Frechtling (1996) and Doswell (1997) agree that some statistical models are difficult to apply to tourism because the complexity of the activity once the tourism supply and demands are under influence of many varieties. That might be one of the reasons for which only a few numbers of studies have been considering the measurement of efficiency for the tourism activity in Brazil. Guimarães et al. (2010) examined the efficiency of Brazilian tourism companies by utilizing the correlation analysis with DEA. The paper dissertation presented by Guimarães (2009) applied stochastic DEA to measure the efficiency of some Brazilian capital cities based on socioeconomic data, similar to the Giaoutzi \& Nijkamp's (2006) research that benchmarked destinations in Italy.

Pessoa, Ferreira \& Fortes (2011) developed a comparative study of social indicators of municipalities that comprise the gold circuit (Minas Gerais - Brazil), pointing to their effects on business tourism demand. Criminal statistics, environment and employment data is applied as well as foreign exchange generation. Assis \& Ferreira (2012) analyzed the efficiency of Latin America countries using HDI (Human Development Index), the amount of private and public investments in tourism along with income and employment impact. However, it is not related directly for Brazilian destinations, but the whole country as a unit.

According to Eugenio-Martin (2003), the choice of destinations involves multiple factors related to decision-making. Both individuals and families with the same socioeconomic and demographic characteristic can choose very different destinations. Due to the nature of the tourism product, the measurement of efficiency is not objective, and traditional productivity concepts are not accurate (Doswell, 1997; Fuchs, 2004). Therefore, there is a need for development of new technologies, so that can create insert tourism accountability to economy, which is essential for the expansion of new destinations and improvement of the quality of services offered (Eugenio-Martin, 2003).

Among some of the barriers for the application of statistical models to tourism is the complexity of the tourism phenomenon, because their demand and its offers is subject to the influence of a multiple variables, making it difficult to explain by quantitative means the subjectivity involved in the tourist trip (Frechtling, 1996; Doswell, 1997). Especially in tourism, which covers other sectors of the economy, new approaches have been developed to place tourism in economic accounting and refine the models used to monitor its performance (Doswell, 1997). The author points out that the input-output approach is related multipliers in order to 
explore how the costs are reflected on the economy, as the multiplier effects reflect on income, employment and government revenue.

A multiplier can also be developed to assess the impact on sales and production. Nevertheless, currently the most used technique to measure these types of effects is the analysis of inputs-outputs. The concept of multiplier is based on the recognition that the sales of a firm require purchases of other companies within the local economy, i.e. the industrial sectors of an economy are interdependent (COOPER, C. Fletcher, J. Fyall, A. Gilbert, D. \& Wanhill, S., 2007).

Conforming to Doswell (1997), the analysis of inputs-outputs in the tourism economy takes into account its structure, as it works an in interdependent system of relationships, where one sector supplies the other sales (output) of a sector and become the input of another sector. Therefore, a model can be developed to simulate the functioning of the economy, reflecting the relationship between inputs and outputs, which can be helpful in the economy forecasting and planning of tourism. Based on the detailed study of economic behavior, a number of input-output coefficients are developed based on different types of transaction. Since the input-output tables are built, the effect of different levels of economic activity can be tracked through the model (Doswell, 1997).

According to Santos \& Fagliari (2003), the availability and statistical data analysis of the activity are based-instruments for study and management of tourism. The tourist universe is influenced by socioeconomic, cultural, political and/or market aspects. Therefore, the statistical projections indicate the behaviour of tourism and its development markets. From these analyzes, statistics can be used as a tool to promote new planning and development of tourist regions (Tiboni, 2003; Stilpen, 2003). Econometrics provides the most appropriate calculation and prediction of some basic results in tourism methods. The econometric models are elaborated from the selection of variables that represent reality and their interrelationship, seeking explanation to the behaviour and the magnitude of the tourism sector in the aspects that want to analyze (Farrel 1957; Franco \& Fortuna, 2003; Rabahy, 2003). That is of utmost importance for managers to conduct properly planning of destinations.

For Chiavenato (2000) planning can be understood as a function that determines in advance what to do and what objectives should be achieved, and aims to give rational conditions to organize and direct departments or divisions from the assumptions of the current and future reality. From a tourism perspective, planning is understood as an activity that provides conditions for achieving objectives, determining methods and techniques leading to environmental, socioeconomic and local development (Ruschmann, 1997). Tourism requires a series of actions and decisions that will only succeed if committed within a systemic process comprising all of governmental efforts, private sector and community. It should be a continuous process within easy interpretation to all individuals involved in order to avoid misunderstanding of the mechanism that might affect negatively the objectives. 


\subsection{The Economic Impact in the Tourism Activity}

Lage and Milone (2000) have shown that tourism has an economic, social, cultural and multiple environmental effects which should not be assumed that the results are equivalent for all aspects and people involved. Despite the activity also provide improvements for locations, it is clear the occurrence of unequal implications in terms of distribution of benefits and costs of tourism. It has to emphasize that any form of economic development will generate impacts on the local population as a result of all kinds of activities and not only the tourism. There are two main factors that may cause positive or negative economic impact for the income of a town due to the tourism: the degree development of the city or community and its capacity, in economic terms, to supply goods and services required by tourism investors.

The economic analysis of tourism is made mainly from the measurement of products (goods and services) that visitors consume during their travels and also the impacts that these products offered has on the macroeconomic variables jointly to the relationship with other activities in the economy (IBGE, 2003). According to Barbosa (2002), the study of the economic impact of tourism can reveal the relationships between sectors of the economy and tourism as well as provides estimates on changes that may occur in the economy after an action. So, a proper using of the economic tourism data requires detailed derivatives of the economic impacts of tourism, as tourists spend their money in a wide variety of goods and services such as transportation, food, and goods in general (Barbosa, 2002). Thus, studies evaluating the impacts of tourism can contribute to the decision-making of governments in relation to tourism, as they can demonstrate the main impacts caused by the activity in a given region, and their respective numbers.

The positive or negative results of the economic impacts of tourism on the destination will depend largely on the degree of development of the region under study, as initially said before. Any industry can lead to two types of effects on the economy: a) intense activity of investment, with periods of expansion due to its implementation; and b) operation itself. However, it notes that in both cases the volume of the impacts will rely on the ability of the local economy to offer the goods and services required by the tourism sector. For example, if a hotel, which is expanding its room capacity, finds every conditions for the construction such as good quality building affordable materials, hand labor, etc., the whole city can benefit from that. Otherwise the investor will get those facilities elsewhere. (Fernandes, 2002 apud Oliveira, 2007).

Ignarra (1999) confirms such sentence by affirming that the impacts might be potentialized according to the type of impact of tourism and the local characteristics. Barbosa (2002) says that the economic impact analysis verifies expenditures associated to tourism, identifying changes in trade, payment of taxes, income generation and jobs due to tourism activity. Although each type of economic analysis has characteristics that distinguish them from each other, they are often misunderstood once that a problem to be analyzed usually requires different types of analyzes. Observe that the analysis of economic impacts of tourism provide estimates of the sector's 
economic interdependencies and a better understanding of the role of tourism in the economy of a given region. Notice here that tourism also involves economic costs, including direct costs incurred by tourism businesses, costs governments with infrastructure to better serve tourists and the costs for individuals in the community, which finance the government beyond taxes payment, and that highlights the importance of local participation in decisions about tourism planning in the region, thereby, making assessment of the benefits and costs generated by the activity (Barbosa, 2002).

Cooper et al. (2001) agrees these economic impacts may be examined in three different levels - the direct, indirect and induced levels. Most direct effects occur within primary tourism sectors in the case, lodging, restaurant, leisure, among others. Through side effects (indirect and induced), tourism affects most sectors of the economy, i.e. the spendings have a "cascade" effect across the local economy, they begin with directly tourists purchasings related to tourism establishments such as hotels, restaurants, transport, and then through the rest of the economy. Stynes (1999) asserts that an analysis of the economic impact of tourism usually focuses on the changes in sales, income, and employment resulting from the tourism activity in a region.

In a review of the economic impact of tourism, it points out that a distinction between the economic impacts caused by tourist expenditure (once it flows into the local economy) and caused by the development of tourism (impacts caused by the construction and the financing of tourism opportunities). It is important to make this distinction, since each type of impact requires a different methodology for evaluation: the tourist spending and their effects should be analyzed by tourism multipliers methodology, while the impacts of the tourism in development need a costbenefit analysis (OMT, 2003).

Figuerola (1992) presents three systems of measure acceptable worldwide: the World Tourism Organization (UNWTO) conducts the first one; the second is the Satellites Account; and the third relates to the input-output matrix. The first is a rating system that aims to standardize worldwide national accounts, based on the following items: a) the value of the tourism production and its components; b) the estimated gross value added (GVA) and tourism incomes; $c$ ) the costbenefit of the investments; d) the impact on domestic economic growth of the locations; e) the gross fixed capital created in the sector and the currency balance of transactions. The second is a highly specialized system of national accounts to better capture the impacts of tourism through a system of complex information. According to Stynes (2002) satellite accounts cover only direct effects and tend to demonstrate the importance or significance of the tourism for a region rather than impact. The third measurement system is an analysis, which aims to calculate the sum of indirect and induced money that tourism generates as well as its disseminations. The matrix of this model exposes the domestic flows between the productive sector of an economy, linking the production of each sector with the intermediate consumption and the final consumption. 


\section{METHODOLOGY}

From 27 State capitals in Brazil 9 had to stay out of the study due to unavailable data, which means that 18 cities were analyzed. Based on the judgmental screening (Golany \& Roll, 1989) and DEA based analysis method (Charnes, Coopers \& Rhodes, 1978) a number of 23 attributes were defined to compound the inputs and outputs to quantify the relative efficiency. So, 15 variables were identified as input and 8 variables as output for the period of 2007, 2008 and 2009. The inputs and outputs was divided as follow:

Table 1 - Variables identified as inputs and outputs

\begin{tabular}{|c|c|}
\hline Inputs & Outputs \\
\hline Investments in commerce and services & Most visited destinations in 2007 \\
\hline Investments in culture & Employments in the food sector \\
\hline Investments in sports and leisure & Employments in the tourism sector \\
\hline Investments in education & Employments in the transport sector \\
\hline Investments in environment management & *IFDM - employment and income \\
\hline Investments in sanitation & **ISSQN - Service taxes \\
\hline Investments in health & Number of air passenger arrivals \\
\hline Investments in safety & Number of terrestrial passenger arrivals \\
\hline \multicolumn{2}{|l|}{ Investments in transportation } \\
\hline \multicolumn{2}{|l|}{ Investments in housing and urban development } \\
\hline \multicolumn{2}{|l|}{ *IFDM - education } \\
\hline \multicolumn{2}{|l|}{ *IFDM - health } \\
\hline \multicolumn{2}{|l|}{ Number of people supplied with sewer service } \\
\hline \multicolumn{2}{|l|}{ Number of people with collecting trash service } \\
\hline \multicolumn{2}{|l|}{ Number of people supplied with clean water } \\
\hline * Firjan Municipal Development Index 2007 & **Service Tax due to any type of service \\
\hline
\end{tabular}

All data used at this research was provided by official departments of the government: the Treasury delivered data about the amount of investments made by the municipalities and service taxes (ISSQN); Air and Terrestrial Transport Agencies (INFRAERO and ANTT) provided the number of passenger arrivals; Labor and Employment Ministry (MTE) gave the number of employment 
created; National Information System on Sanitation (SNIS) had number of people with access to clean water, collecting trash service and sewer service. For data about the most visited cities was checked the publishing study made by Ministry of Tourism in partnership with the Institute for Economic Research (FIPE) that had information for only 2007. In 2008 and 2009 was used the same data of 2007.

To calibrate data according to the size of each city all information numbers was divided by the population of each capital, giving a per capita data. I.e. big cities like São Paulo that will probably create much more job vacancies than smaller ones like Natal. So, the number of jobs generated was divided by the population of each capital, which gave a statistical equalization.

To analyze the data available and split them into inputs and outputs the used criteria based on the linear correlation between the variables, which is also known as Pearson product-moment correlation coefficient. Triola (2005) and Gujarati (2006) agree that the linear correlation coefficient $r$ is the measure to determine the intensity between two variables. That implies a $x y$ relation $\left(r_{\mathrm{xy}}\right)$ which is calculated from the covariance between $x$ and $y(\operatorname{cov} x y)$ and its standard deviation $\left(s_{x}\right.$ and $\left.s_{y}\right)$ given by the formulae:

$$
\operatorname{cov} x y=\frac{\left(x_{1}-\bar{x}\right)\left(y_{1}-\bar{y}\right)+\left(x_{2}-\bar{x}\right)\left(y_{2}-\bar{y}\right)+\cdots+\left(x_{N}-\bar{x}\right)\left(y_{N}-\bar{y}\right)}{N}=\frac{1}{N} \sum\left(x_{1}-\bar{x}\right)\left(y_{1}-\bar{y}\right)
$$

The correlation $r_{x y}$ is defined by:

$$
\text { Correlation }=r_{x y}=\frac{\operatorname{cov} x y}{s_{x} s_{y}}
$$

The result will vary from the value -1.00 , which represents a perfect negative correlation, while a 0.00 value indicates no correlation and $a+1.00$ indicates a perfect positive correlation. $A$ perfect negative correlation means that the relationship, which appears to exist between two variables, is negative $100 \%$ of the time. All interpretations of the relationships between variables have to be under the Pearson correlation values to check the existence of a significant correlation or whether the variable should be excluded.

The definition of inputs and outputs constitute the baseline for DEA, if so the variable that presents high correlation with others might be excluded, as mentioned before. In that case, in order to accurate the results and reduce variables for running DEA, the factor analysis was applied using the Statistical Pack for Social Sciences - SPSS, which is a very important tool for social and human sciences so as to analyze data (Field, 2005; Oliveira, 2008). This software was applied to this paper in the 16.0 version. While running data, the extraction method settings based on: principal components, Eigenvalues over 1 and Varimax rotation. 
After extraction from SPSS the inputs and outputs for running DEA was analyzed using the Microsoft Office Excel 2010 version. The output-oriented DEA analysis was applied based on the CCR model that evaluated the efficiency of each city or DMU (i) by the formulation:

$$
\text { Efficiency of the unit } \mathrm{i}=\frac{\text { weighted sum of outputs of the units } \mathrm{i}}{\text { weighted sum of inputs of the units } \mathrm{i}}=\frac{\sum_{j=1}^{n_{O}} O_{i j} w_{j}}{\sum_{j=1}^{n_{I}} I_{i j} v_{j}}
$$

$\mathrm{O}_{\mathrm{ij}}$ represents the value of the unit $\mathrm{i}$ at the output $\mathrm{j}, \mathrm{I}_{\mathrm{ij}}$ represents the value of the unit $\mathrm{i}$ at the input $j, w_{j}$ represents a not negative weight declared in the output $j, v_{j}$ represents a not negative weight declared in the input $j, n_{0}$ is the number of output variables and $n_{1}$ is the number of input variables. The problem is set on determine values for the weight $w_{j}$ e $v_{j}$, then $w_{j}$ and $v_{j}$ represent the decision-making variables in the problem.

A problem separated from Linear Programming (LP) is solved in each DEA unit, however for each unit the objective is the same: maximize the considered sum of the outputs. So for each unit (i) the objective set is given by:

$$
\text { MAX: } \sum_{j=1}^{n_{o}} O_{i j} w_{j}
$$

By the time that each LP problem is solved the unit under investigation allow to select the best possible weights for it, which is oriented by restrictions:

$$
\sum_{j=1}^{n_{o}} O_{k j} w_{j} \leq \sum_{j=1}^{n_{1}} I_{k j} v_{j} \text { for } k \text { between } 1 \text { to the number of units }
$$

It is not possible for any unit get more than 100 percent efficient because none of its outputs can be increased without increasing one or more of its inputs or decreasing some of its other outputs. Equally none of its inputs can be decreased without decreasing some of its outputs or increasing some of its others inputs (Wober \& Fesenmaier, 2004).

Or equivalent

$$
\sum_{j=1}^{n_{0}} O_{k j} w_{j}-\sum_{j=1}^{n_{1}} I_{k j} v_{j} \leq 0 \quad \text { for } k \text { between } 1 \text { to the number of units }
$$


To avoid unlimited solutions it is demanded that the weighted sum of inputs of the unit (i) under investigation has to be equal to 1.

$$
\sum_{j=1}^{n_{1}} I_{i j} v_{j}=1
$$

Then as the weighted sum of inputs have to be 1 and the weighted sum of outputs (maximized) must not pass over this value (1) the maximum rank for the unit is also 1 (or 100\%) which means that units are efficient when they rate $100 \%$.

\section{RESULTS AND DISCUSSIONS}

According to the methodology proposed before, the factor analysis process was applied before running DEA, and from that it emerged five components for the inputs and two for the outputs in the 2007 results. For both 2008 and 2009 years the factor analysis extracted four inputs and three outputs. Given to all extractions were well succeeded the next part calculated the relative efficiencies of DMU's (or cities). DEA outcomes showed that from the 18 State capitals analyzed 9 reached the efficiency $100 \%$ in 2007. However, the number of capitals $100 \%$ efficient decreased consecutively in 2008 and 2009, ranging respectively 7 and 6 capitals. We present in Table 1 the results for the 2007-2009 periods. The efficiency scores, stretching between 0 and 1, define a rank of the Brazilian State capitals. The value 1 (100\%) corresponds to the most efficient tourism destination city and the value $0(0 \%)$ relates to the least efficient tourism destination city. A unit with a score of less than $100 \%$ is relatively inefficient, i.e. a unit with a score of 0,90 is only $90 \%$ as efficient as the best performing DMU. 
Table 2 - DEA efficiency scores for the Brazilian State capitals, 2007-2009

\begin{tabular}{|c|c|c|c|c|}
\hline \multirow[b]{2}{*}{ CAPITAL } & \multicolumn{4}{|c|}{ DEA EFFICIENCY } \\
\hline & 2007 & 2008 & 2009 & Average \\
\hline Belém & 1,00 & 1,00 & 0,78 & 0,93 \\
\hline Belo Horizonte & 1,00 & 1,00 & 0,79 & 0,93 \\
\hline Cuiabá & 1,00 & 0,00 & 1,00 & 0,67 \\
\hline Curitiba & 0,52 & 0,70 & 0,72 & 0,65 \\
\hline Florianópolis & 1,00 & 0,39 & 1,00 & 0,80 \\
\hline Fortaleza & 1,00 & 1,00 & 0,80 & 0,93 \\
\hline Goiânia & 1,00 & 1,00 & 1,00 & 1,00 \\
\hline João Pessoa & 0,43 & 0,97 & 0,30 & 0,57 \\
\hline Maceió & 0,25 & 0,88 & 0,56 & 0,56 \\
\hline Manaus & 0,54 & 0,35 & 0,44 & 0,44 \\
\hline Natal & 0,97 & 0,41 & 0,69 & 0,69 \\
\hline Porto Alegre & 1,00 & 0,94 & 0,88 & 0,94 \\
\hline Recife & 0,39 & 0,35 & 0,90 & 0,55 \\
\hline Rio de Janeiro & 0,75 & 0,56 & 0,85 & 0,72 \\
\hline Salvador & 0,54 & 1,00 & 1,00 & 0,85 \\
\hline São Luís & 0,52 & 0,43 & 0,36 & 0,44 \\
\hline São Paulo & 1,00 & 1,00 & 1,00 & 1,00 \\
\hline Vitória & 1,00 & 1,00 & 1,00 & 1,00 \\
\hline
\end{tabular}

Throughout 2007, 2008 and 2009 only three destinations succeeded the top 100\% efficiency: Goiânia, São Paulo and Vitória. Traditionally tourism destinations as Rio de Janeiro, Curitiba, Maceió, Natal and Recife did not achieve $100 \%$ at any year of the research. In the case of Rio de Janeiro, Curitiba and Recife, such a result are due to the higher cost that these big metropolis have to maintain basic needs like health, education and security, consequently investing more than other destinations to receive visitors and create jobs, as it may be found on data about investments.

On the other hand, cities with no traditional tourism activity like Goiânia and Cuiabá had stood out in the entire research. That is explained mainly by the large number of air passenger arrivals received by Goiânia (a hub commercial city) while it is notably that Cuiabá is very sensible to the amount of employments generated as well as the quantity of tourists visiting the city, which 
contributed for the good results in 2007, 2009 and for the worst score in 2008. As pointed out by some authors, the economic impact of visitors expenditure was crucial for Cuiabá once the number of tourists had direct impact in job creations, showing the significance of tourism for the city, but not its impact (Cooper et al., 2001; Barbosa, 2002; \& Stynes, 2002).

The high score reached by Vitória is due to the employments generated, specifically in the food sector, where the city ranked the highest mark as well as the highest number of air passenger arrivals, which is also big for a middle city. In this case, this study contributes for the evaluation of impacts of tourism, providing important information for government decision-making, very well highlighted by Barbosa (2002), when the author said that tourists spend their money in a wide variety of goods and services such as transportation, food, and goods in general. Even further, it is possible to realize here the potential economic impact of tourism in Vitória if we take into account the "cascade" effect of tourist purchasings, stressed by Cooper et al. (2001), since air transportation and food sector have indirect effect through the rest of the economy.

Concerning about the variable that really made the difference for São Paulo, the "Most visited cities in 2007" acted as the most important factor for the destination excellent scores, even though São Paulo produces many vacancies in job market, that issue was not the main reason for such a result.

Through the three-year-period of the research, some destinations appeared in a regular variation. That was the case of Belém, Belo Horizonte, Curitiba, Fortaleza, Manaus, Porto Alegre, Rio de Janeiro and São Luís. However destinations as Cuiabá, Florianópolis, João Pessoa, Maceió, Natal, Recife and Salvador demonstrated a huge difference between the efficiency values during the years, which means how vulnerable they are to some specific factors like creation of jobs for Cuiabá, Florianopópolis, João Pessoa, Maceió and Recife. Salvador has a very good air passenger flow, but lacks in employments creation, while Natal faces a mixture of good and bad scores in passengers flow and jobs generation.

Others two destinations caught the attention in the study - Florianópolis and Manaus. The first one did not reach the average $100 \%$ because its bad results in 2008 , when it was not efficient to generate more jobs. Such information might be used by government to investigate profounder the elements that caused decreasing rate for the city. Manaus appears as an interesting case because it is the gate for entrance in the Amazon in Brazil; nevertheless it has developed a very poor result in the entire research. Actually, worse than that, it ranked the last position together to São Luís. Its inefficiency mostly due to few passenger arrivals, low capacity to develop more employments, and insufficient number of visitors. This information reveals important elements for public managers because it shows the real needs of investments in the city of Manaus, which are terminals for passengers (airports, ports, bus stations) in what could lead to the increasing in the number of tourists that in turn might create more job opportunities.

The linking of variables is described by IBGE (2003) that says that goods and services consumed by visitors during their travels produce impacts on the macroeconomic variables jointly to the relationship with other activities in the economy. Manaus might have the impacts of 
tourism potentialized positively, as Ignarra (1999) affirms the impacts are accordingly to the type of local characteristics, in this case hand labor for construction, and goods and services as well.

For an overall evaluation it is clear that the performances of destinations are affected by some specific drivers as demonstrated in Manaus, Florianópolis, Cuiabá, and Goiânia. Those drivers might be managed by authorities and local governments that possess the tools to contribute to the increasing of determinant sectors if investments are made on such important sectors, demonstrating how the activity may cause impacts in a given region and such results depends primary of the decision making of public sector and secondly of private investments.

\section{CONCLUDING REMARKS}

The main purpose of this study was to provide a benchmarking analysis to contribute to the tourism literature by offering new insights into the performance assessment of tourism destinations in Brazil as well as apply DEA model to achieve such a goal. Several interesting and useful insights were discussed showing that some destinations like Manaus, Natal and Recife have the opportunity to take advantage from the soccer world cup in 2014 to improve the offer of employments, which might increase its scores in the future. The core challenge for managers it is how to keep sustainable such increasing after the huge and momentary event. On the other side João Pessoa, Maceió and São Luís have to find strategies for its bad results in order to enlarge their air passenger flow and employments vacancy.

Finally, even though this research was based on an output-oriented analysis we have to point out the very significant role in which the investments on education played for the best results of the top destinations. Undoubtedly the studies exposed that this precise input variable correlate proportionally to the best DEA perform, which means that the more a destination spends or invests on education more employments, passenger arrivals and visitors it will receive. That is not surprising because it is known that the more education a society has less violent and consequently safer the city will be for tourists. Of course many other factors influence in the tourism demand however this indicator revealed as very important for the findings.

In summary, it is possible to relate the efficiency of destinations to several other factors. A major limitation of this study is the inexistence of data in some sector and destinations. For example a hotel occupancy rate might play a decisive frontier for some cities, although only few locations run annual data research. We have also limited number of years with available data. Therefore, the results might have been influenced by recent trends such the financial crisis which implies that a comparison should be taken with caution. Because that we suggest future researches in longer period introducing, when possible, new data to the studies.

\section{REFERENCES}

Aranha, F. \& Zambaldi, F. (2008). Análise fatorial em administração. 1. ed. São Paulo: Cengage Learning. 
Assis, K. V. \& Ferreira, W. R. (2012). Análise comparativa temporal de eficiência de demanda turística e socioeconômica de países Latino-Americanos, pela análise por envoltória de dados - DEA. Revista Pensar, Gestão e Administração. 1 (2).

Barbosa, L. G. M. (2002). Os impactos econômicos do turismo e sua implicação nas políticas públicas: o caso do município de Macaé-RJ, Brasil. VII Congreso Internacional del CLAD sobre la Reforma del Estado y de la Administración Pública, Lisboa, Portugal. Retrieved from http://unpan1.un.org/intradoc/groups/ public/documents/CLAD/clad0044545.pdf

Barros, C. (2005). Measuring efficiency in the hotel sector. Annals of Tourism Research. 32(2), 456-477.

Barros, C. P. Botti, L. Peypoch, N. Robino, E. Solonandrasana, B. \& George, A. (2011). Performance of French destinations: Tourism attraction perspectives. Tourism Management. 32. 141-146.

Charnes, A. Cooper, W.W. \& Rhodes, E. (1978). Measuring the efficiency of decision making units. European Journal of Operational Research. 2. 429-444.

Chiavenato, I. (2000). Administração: Teoria, processo e prática. (3ạ ed). São Paulo: Makron Books, 2000.

Cooper, C. Fletcher, J. Fyall, A. Gilbert, D. \& Wanhill, S. (2007). Turismo: Princípios e práticas. (3a ed). São Paulo: Bookman.

Doswell, R. (1997). Tourism: How effective management makes the difference. Oxford: Butterworth Heinemann.

Eugenio-Martin, J. (2003) Modelling determinants of tourism demand as a five-stage process: A discrete choice methodological approach. Tourism and Hospitality Research. 4 (4) 341-354.

Farrel, M. J. (1957). The measurement of productive efficience. Journal of the Royal Statistical Society. series A. part III. 120 (3), 253-290.

Field, A. (2005). Discovering statistics using SPSS: (and sex, drugs and rock'n roll). (3a ed). Los Angeles: Sage Publications.

Figuerola, M. (1992). Manual para el estudio de la economia turística en el ámbito macroeconômico. Madrid: OMT. 302 p.

Franco, F. Fortuna, M. (2003). O Método de fronteira estocástica na medição da eficiência dos serviços hospitalares: Uma revisão bibliográfica. (2). Associação Portuguesa de Economia e Saúde - APES. Portugal: Universidade Nova de Lisboa.

Frechtling, D. C. (1996). Practical Tourism Forecasting. Oxford, UK: Butterworth-Heinemann.

Fuchs, M. (2004). Strategy development in tourism destinations: A DEA approach. Poznan University Economics Review. 4 (1), 52-73.

Giaoutzi, M. \& Nijkamp, P. (2006). Tourism and regional development: New pathways. Economic geographic series. Aldershot, UK: Ashgate, 133-152.

Golany, B. \& Roll, Y. (1989). An application procedure for DEA. Omega International Journal of Management Science. 17 (3) 237-250.

Green, P. \& Carrol, J. (1976). Mathematical tools for applied multivariate analysis. New York: Academic Press.

Guimarães, F. (2009). Aplicação de uma técnica de análise por envoltória de dados estocástica (DEAEstocástica) para análise socioeconômica de capitais brasileiras, com especial enfoque em demanda turística. (Dissertação de mestrado, Centro Universitário UNA, Belo Horizonte, Brazil). 
Guimarães, F. A. R. Fortes, M. Ferreira, W. R. \& Paiva, R. V. C. (2010). O método DEA e análise de correlação para avaliação de eficiência de empresas com aplicação a empresas turísticas. Revista Turismo Visão $e$ Ação. 12 (3) 258-276.

Gujarati, D. N. (2006). Econometria básica. Tradução Maria José Cyhlar Monteiro. Rio de Janeiro: Elsevier. Gunn, C. (1994). Tourism planning (3a ed). London: Taylor and Francis.

Hair Jr., J. F. Black, W. C. Babin, B. J. Anderson, R. E. \& Tathan, R. L. (1998). Multivariate data analysis. (5a ed). New York: Macmillan Publishing Company.

IBGE - Instituto Brasileiro de Geografia e Estatística (2003). Economia do turismo: Análise das atividades características do turismo 2003. (5). Estudos \& Pesquisas, Informações econômicas. Retrieved from http://www.ibge.gov.br/home/estatistica/economia/industria/economia_turismo/economia_turismo.pdf

Ignarra, L. R. (1999). Fundamentos do turismo. São Paulo: Pioneira.

Johnson, R. A. \& Wichern, D. W. (1998). Applied Multivariate Statistical Analysis. (4a ed). New Jersey: Upper Saddle River.

Lage, B. H. G. \& Milone, P. C. (2000). Turismo: teoria e prática. São Paulo: Atlas.

Leibenstein, H. (1966). Allocative efficiency vs. 'X-efficiency'. American Economic Review. 56. 392-415.

Malhotra, N. K. (2004). Pesquisa de marketing: Uma orientação aplicada. (4ạ ed). Porto Alegre: Bookman.

Marinho, A. (1996). Avaliação organizacional de uma universidade pública: Uma abordagem nãoparamétrica da Universidade Federal do Rio de Janeiro. (Tese de doutorado, Fundação Getúlio Vargas, Rio de Janeiro, Brasil).

McGarvey, B. \& Hannon, B. (2004). Dynamic modeling for business management: An introduction. New York: Springer.

Medina, L. F. Gómez, I. G. \& Marrero, S. M. (2012). Measuring efficiency of sun \& beach tourism destinations. Annals of Tourism Research. 39 (2). 1248-1251.

Oliveira, E. S. (2007). Impactos socioambientais e econômicos do turismo e suas repercussões do desenvolvimento local: O caso do município de Itacaré - Bahia. Iterações, Revista Internacional de Desenvolvimento Local. 8 (2) 193-202. Retrieved from http://www.scielo.br/pdf/inter/v8n2/ a06v08n2.pdf

Oliveira, F. (2008). SPSS Básico para análise de dados. (1ae ed). Rio de Janeiro: Ciência Moderna.

OMT- Organização Mundial do Turismo. (2003). Turismo internacional: Uma perspectiva global. (2a ed). Porto Alegre: Bookmann.

Pessoa, F. J. M. Ferreira, W. R. \& Fortes M. (2011). Análise da eficiência turística do circuito do ouro (MG) pelo método DEA-estocástica, com inclusão do efeito de criminalidade. Sustentabilidade na cadeia de suprimentos. XVIII Simpósio de Engenharia de Produção. Bauru, SP.

Rabahy, W. A. (2003). Turismo e desenvolvimento: Estudos econômicos e estatísticos no planejamento. (1 ed). v. 1. Baruerí, SP: Editora Manole.

Ruschmann, D. V. M. (1997). Turismo e planejamento sustentável: A proteção do meio ambiente. (6a ed). São Paulo: Papirus.

Santos, G. E. O. Fagliari, G. S. (2003). Práticas e usos da estatística no turismo. Revista Eletrônica de Turismo. 2 (2) 1-7.

Shu, T. Zhong, X. \& Zhang, S. (2011). TFP Electricity consumption efficiency and influencing factor analysis based on DEA method. Energy Procedia. 12, 91-97. 
Souza, U. R. (2008). Eficiência técnica e de escala das cooperativas agropecuárias do Estado do Paraná. (Dissertação de mestrado, Universidade Federal de Viçosa, Viçosa, Brasil).

Stilpen, P. C. (2003). Utilização de estatísticas e de cenários como instrumentos necessários ao planejamento e à gestão do turismo. Observatório de Inovação do Turismo. EMBRATUR - FGV.

Stynes, D. J. (1999). The economic impacts of tourism. Michigan State University. Retrieved from https://www.msu.edu/course/prr/840/econimpact/pdf/ecimpvol1.pdf

Stynes, D. J. (2002). Michigan statewide tourism spending and economic impact estimates 1998-2000. Retrieved from http://www.prr.msu.edu/miteim/MichiganSatExec.pdf

Tiboni, C. G. R. (2003). Estatística básica para o curso de turismo. (2ª ed). São Paulo: Atlas.

Triola, M. F. (2005). Introdução à estatística. (9a ed). Rio de Janeiro: LTC.

Tupi, O. \& Yamaguchi, L. C. (1998). Eficiência e produtividade: Conceitos e medição. Agricultura em São Paulo. 45(2), 39-51.

UNWTO (2010). World Tourism Barometer. World Tourism Organization, Madrid. 8 (3).

UNWTO (2011). Tourism Towards 2030 - Global Overview. World Tourism Organization, Madrid.

UNWTO (2012). World Tourism Barometer. World Tourism Organization, Madrid. 10.

Wober, K. \& Fesenmaier, D. (2004). A Multi-criteria approach to destination benchmarking: A case study of state tourism advertising programs in the United States. Journal of Travel and Tourism Marketing. 16 (2), 118.

WTTC/OXFORD ECONOMICS. (2011). World Travel and Tourism Council. Travel \& Tourism 2011. Published in partnership with Oxford Economics. London.

Artigo recebido em: $21 / 03 / 2014$.

Artigo aprovado em: 24/03/2015. 